\title{
PEMBUATAN MEDIA KARTU SOAL PERHITUNGAN PH PADA MATERI POKOK LARUTAN PENYANGGA DI SMAN 1 JENAMAS
}

\author{
Novrian Dony ${ }^{1}$, Jurniah ${ }^{2}$, Herlina Apriani ${ }^{3)}$ \\ ${ }^{1}$ FKIP, Universitas Islam Kalimantan Muhammad Arsyad Al- Banjari Banjarmasin \\ 1)email: n.dony@uniska-bjm.ac.id \\ ${ }^{2}$ FKIP, Universitas Islam Kalimantan Muhammad Arsyad Al- Banjari Banjarmasin \\ ${ }^{2)}$ email: jurniahsuriani@yahoo.co.id \\ ${ }^{3}$ FKIP, Universitas Islam Kalimantan Muhammad Arsyad Al- Banjari Banjarmasin \\ ${ }^{3)}$ email: herlina_apriani@yahoo.com
}

\begin{abstract}
This study aims to produce learning media in form question card for calculating $\mathrm{pH}$ on buffer material in Jenamas 1 Public High School. The media card of this question was made with the Research and Development method through Borg and Gall process steps consisting of research and data collection information, planning, product design development, field testing and design (product) revisions, final design revisions, and desemination / implementation. The results of the feasibility test of the card about the feasibility of content, language, graphics, and presentation by the validator get an average value of $98.6 \%$ with a very feasible ratio. In just a small scale trial the average score is 16.9 with a very good category, while for large scale the average score is 19.6 with a very good category. Use it from the search for the situation above so that card media from abroad can be represented as learning media.
\end{abstract}

Keywords: Learning Media; Question Card; Media Feasibility

Abstrak: Penelitian ini bertujuan untuk menghasilkan media pembelajaran kimia berupa kartu soal untuk perhitungan pH pada materi larutan penyangga di SMA Negeri 1 Jenamas. Media kartu soal ini dihasilkan dengan metode Penelitian dan Pengembangan menurut Borg and Gall melalui langkah - langkah proses yang terdiri dari penelitian dan pengumpulan data informasi, perencanaan, pengembangan desain bentuk awal produk, uji lapangan dan revisi desain (produk), revisi desain akhir, dan deseminasi/ implementasi.. Hasil uji kelayakan media kartu soal kelayakan isi, bahasa, kegrafisan, dan penyajian oleh validator mendapatkan skor rata - rata sebesar 98,6\% dengan kriteria sangat layak. Pada uji coba skala kecil mendapatkan rata-rata skor sebesar 16,9 dengan kategori sangat baik, sedangkan untuk skala besar mendapatkan rata - rata skor sebesar 19,6 dengan kategori sangat baik. Berdasarkan dari hasil penelitian diatas maka dapat disimpulkan media kartu soal layak digunakan sebagai media pembelajaran.

Kata Kunci : Media Pembelajaran; Kartu Soal;Kelayakan Media 


\section{PENDAHULUAN}

Pendidikan bertujuan untuk membentuk kualitas dan mengembangkan potensi diri yang memiliki peran yang sangat penting untuk kemajuan bangsa dan negara. Pendidikan diharapkan memiliki mutu yang baik agar kemajuan bangsa dan negara dapat terwujud. Pada proses pembelajaran sangat diharapkan dapat menggali dan mengembangkan potensi yang ada pada peserta didik agar mereka memiliki kepribadian, kecerdasan, serta keterampilan. Dalam upaya peningkatan mutu pendidikan, dapat dilakukan dari propesionalisme guru dalam proses pembelajaran. Seorang guru harus memiliki 4 kompetensi berupa penguasaan bidang studi, pemahaman peserta didik, melakukan proses belajar yang mendidik, dan pengembangan kepribadian dan kepropesionalan (Marsiti, 2011) (Novauli, 2015).

Proses pembelajaran yang diterapkan oleh guru di sekolah diharapkan mampu membuat peserta didik paham dan mengerti dengan baik materi yang disampaikan oleh guru. Membuat peserta didik paham dan mengerti bukan hal yang mudah. Kesulitan siswa yang paling banyak dan mencolok pada pelajaran kimia terletak pada perhitungan (Yakina dkk., 2017). Di Pemalang, siswa masih mengalami kesulitan dalam memahami materi larutan penyangga pada perhitungan $\mathrm{pH}$ (Marsita dkk., 2010). Selain akibat kesulitan dalam memahami, miskonsepsi masih ditemukan walau sudah diminimalisir dengan pendekatan Dual Situated Learning Model (DSLM) yang dibantu animasi akibat dari siswa masih mengacu kepada konsep perhitungan asam-basa materi sebelumnya (Maratusholihah dkk., 2017a). Di SMAN 1 Jenamas ditemui kasus pada perhitungan $\mathrm{pH}$ hanya $25 \%$ peserta didik yang menjawab benar. Angka ini relative sangat kecil. Oleh karena itu perlu dilakukan upaya untuk menyelesaikan permasalahan ini.

Telah dilakukan banyak upaya untuk meningkatkan pemahaman dan pengertian siswa terhadap materi larutan penyangga ini.
Upaya dengan penggunaan model pembelajaran dengan direct instruction disertai hierarki konsep dan telah mampu mengurangi miskonsepsi siswa (Yunitasari dkk., 2013). Mengembangkan lembar Kerja Siswa (LKS) praktikum berbasis inkuiri terbimbing (Pratiwi, 2015). Penerapkan Model Pembelajaran Berbasis Masalah yang telah mampu meningkatkan prestasi belajar berupa kognitif dan afektif siswa (Assriyanto dkk., 2014). Penggunaan pendekatan SAVI (Somatis, Auditori, Visual, dan Intelektual) dengan menggunakan panduan dan $\mathrm{CD}$ praktikum untuk meningkatkan hasil belajar (Rahmadhani dkk., 2013). Menggunakan media pembelajaran dengan menggunakan program Macromedia flash yang telah mampu meningkatkan hasil belajar (Badlisyah dan Maghfirah, 2017). Namun yang dilakukan ini terfokus keseluruhan isi pada materi larutan penyangga.

Salah satu upaya yang menarik untuk menyelesaikan masalah ini adalah dengan menggunakan media pembelajaran berupa kartu (Dony dkk., 2018). Menurut peneliti jenis kartu yang tepat adalah kartu soal. Sejauh ini belum ada diteliti pembuatan kartu soal untuk materi larutan penyangga. Pada penelitian ini akan dibuat media pembelajaran berupa kartu soal untuk perhitungan $\mathrm{pH}$ larutan penyangga yang layak untuk disajikan di SMAN 1 Jenamas.

\section{METODE PENELITIAN}

Media pembelajaran kartu soal untuk perhitungan $p \mathrm{H}$ larutan penyangga dibuat dengan menggunakan penelitian Penelitian dan pengembangan. Dengan mempertimbangan tujuan yang diharapkan, desain penelitian ini menggunakan penelitian dan pengembangan menurut Borg dan Gall dan berbeda dengan penelitian terdahulu yang menggunakan model ADDIE (Dony dkk., 2018). Langkah-langkah terdiri dari penelitian dan pengumpulan data informasi, perencanaan, pengembangan desain bentuk awal produk, uji lapangan dan revisi 
desain (produk), revisi desain akhir, dan deseminasi/ implementasi.

Penelitian dan pengumpulan data informasi dilakukan dengan menggunakan wawancara dengan guru dan kajian literature/ referensi. Dengan ini, peneliti akan memiliki kerangka untuk perencanaan membuat desain media kartu. Selanjutnya dilakukan pengembangan desain bentuk awal produk. Pengembangan desain ini divalidasi oleh ahli yang terdiri dari dua orang guru dan satu orang dosen yang ahli dibidangnya. Analisa data menggunakan data deskriptif kualitatif dengan memberikan gambaran dan paparan, serta saran terkait desain media, kelayakan isi, bahasa, kegrafisan dan sajian desain yang dihasilkan. Pada teknis analisis data pada hasil validasi menggunakan skala Guttman sebagai mana ditampilkan pada tabel 1.

\begin{tabular}{cc}
\hline Jawaban & Nilai \\
\hline Tidak & 1 \\
\hline Ya & 2
\end{tabular}

Table 1. Skala Guttman

Skor yang diperoleh oleh validator diolah dengan menggunakan teknik analisi deskriftif dalam bentuk persentase. Rumus yang digunakan adalah:

$$
\text { Persentase }=\frac{\text { zskorpenilavan angket }}{\text { zskor maksumum }} \times 100 \%
$$

Persentase hasil validasi yang diperoleh kemudian dikategorikan berdasarkan kriteria menurut Sudjana (Nana, 2004). Tabel 2, menunjukkan kriteria interprestasi penilaian kelayakan media kartu soal.

\begin{tabular}{ccc}
\hline Skor (\%) & Kriteria & Kategori \\
\hline $81-100$ & Sangat layak & $\begin{array}{c}\text { Tidak perlu } \\
\text { revisi }\end{array}$ \\
\hline $66-80$ & Layak & $\begin{array}{c}\text { Tidak perlu } \\
\text { revisi }\end{array}$ \\
\hline $56-65$ & Kurang layak & Perlu revisi \\
\hline$<55$ & $\begin{array}{c}\text { Sangat tidak } \\
\text { layak }\end{array}$ & Perlu revisi \\
&
\end{tabular}

Tabel 2. Kriteria interprestasi penilaian kelayakan media kartu soal Pengembangan desain ini dilakukan sampai memenuhi kriteria sangat layak atau layak oleh validator. Selanjutnya dilakukan ujicoba lapangan dan revisi desain akhir. Hal ini dilakukan dengan uji skala kecil dan besar. Uji coba skala kecil (small group evaluation) dilakukan pada 10 orang siswa kelas XII IPA di SMA Negeri 1 jenamas. Lembar pertanyaan/angket ditunjukkan pada tabel $\mathbf{3}$ dan kriteria interprestasi penilaian kelayakan media kartu soal skala kecil pada table 4.

\begin{tabular}{cl}
\hline No. & Pernyataan \\
\hline 1 & $\begin{array}{l}\text { Tampilan fisik media kartu soal ini } \\
\text { menarik }\end{array}$ \\
\hline 2 & $\begin{array}{l}\text { Petunjuk penggunaan kartu soal ini } \\
\text { mudah saya pahami }\end{array}$ \\
\hline 3 & $\begin{array}{l}\text { Urutan penyajian materi kartu soal ini } \\
\text { jelas }\end{array}$ \\
\hline 4 & $\begin{array}{l}\text { Uraian materi pada kartu soal ini mudah } \\
\text { dipahami }\end{array}$ \\
\hline 5 & $\begin{array}{l}\text { Soal dan petunjuk evaluasi pada media } \\
\text { kartu soal membantu meningkatkan } \\
\text { pemahaman terhadap materi larutan } \\
\text { penyangga }\end{array}$ \\
\hline 6 & $\begin{array}{l}\text { Bahasa pada media kartu soal mudah } \\
\text { dipahami }\end{array}$ \\
\hline 7 & $\begin{array}{l}\text { Media ini mampu membangkitka } \\
\text { motivasi belajar }\end{array}$ \\
\hline 8 & $\begin{array}{l}\text { Tulisan yang digunakan dalam media } \\
\text { kartu soal mudah dibaca }\end{array}$ \\
\hline 9 & $\begin{array}{l}\text { Media kartu soal ini bermanfaat sebagai } \\
\text { media dan sumber belajar materi larutan } \\
\text { penyangga }\end{array}$ \\
\hline
\end{tabular}

Tabel 3. Lembar pertanyaan/angket skala kecil

\begin{tabular}{cc}
\hline Skor & Kategori \\
\hline $9-11$ & Tidak Baik \\
\hline $12-14$ & Baik \\
\hline $15-18$ & Sangat Baik
\end{tabular}

Table 4. kriteria interprestasi penilaian kelayakan media kartu soal skala kecil.

kemudian masuk ketahap uji coba skala besar (field evaluation) yang dilakukan pada siswa kelas XI IPA di SMA Negeri 1 Jenamas dengan jumlah total siswa sebanyak 16 orang. Lembar pertanyaan/angket-nya ditunjukkan pada tabel 5 dan kriteria interprestasi penilaian 
kelayakan media kartu soal skala besar pada table 6.

\begin{tabular}{|c|c|}
\hline No. & Pernyataan \\
\hline 1 & $\begin{array}{l}\text { Media kartu soal dapat memudahkan } \\
\text { saya dalam mempelajari materi larutan } \\
\text { penyangga }\end{array}$ \\
\hline 2 & $\begin{array}{l}\text { Media kartu soal dapat menumbuhkan } \\
\text { motivasi saya untuk belajar materi } \\
\text { larutan penyangga }\end{array}$ \\
\hline 3 & $\begin{array}{l}\text { Penggunaan media kartu soal dapat } \\
\text { membuat saya aktif dalam pembelajaran } \\
\text { materi larutan penyangga }\end{array}$ \\
\hline 4 & $\begin{array}{l}\text { Media kartu soal membangkitkan rasa } \\
\text { ingin tahu saya tentang materi larutan } \\
\text { penyangga }\end{array}$ \\
\hline 5 & $\begin{array}{l}\text { Penggunaan media kartu soal memberi } \\
\text { saya kesempatan untuk berinteraksi } \\
\text { dengan siswa lain }\end{array}$ \\
\hline
\end{tabular}

6 Latihan -latihan yang ada pada media kartu soal sangat membantu saya untuk lebih mempelajari materi larutan penyangga

7 Penggunaan media kartu soal tetap memberi saya kesempatan untuk bertanya selama proses pembelajaran

8 Media kartu soal menjadikan pembelajaran materi larutan penyangga lebih menarik

9 Saya menyukai desain media kartu soal pada materi larutan penyangga

10 Menurut saya secara umum media kartu soal ini layak digunakan dalam pembelajaran materi larutan penyangga

Tabel 5. Lembar pertanyaan/angket skala kecil

\begin{tabular}{cc}
\hline Skor & Kategori \\
\hline $10-12$ & Tidak Baik \\
\hline $13-16$ & Baik \\
\hline $17-20$ & Sangat Baik
\end{tabular}

Table 6. kriteria interprestasi penilaian kelayakan media kartu soal skala kecil.

Ujicoba lapangan dan revisi desain akhir ini berupa data deskriptif kualitatif yang berisi alasan dan skala Guttman yang menunjukan tingkat validasi kelayakan kartu soal sebagai media atau sumber belajar. Tahap deseminasi/ implementasi dilakukan dengan penyebaran menggunakan media ilmiah/publikasi

\section{HASIL DAN PEMBAHASAN \\ Penelitian, Pengumpulan Data, dan Informasi}

Penelitian, pengumpulan data dan informasi ditujukan untuk mendapatkan dan menganalisa data yang ada, mengidentifikasi, menganalisis potensi dan masalah di sekolah SMA Negeri 1 Jenamas. Hal ini didapatkan dengan mewawancarai guru mata pelajaran kimia kelas XI IPA. Hasilnya menunjukkan bahwa rata-rata hasil belajar siswa pada meteri larutan penyangga rendah dalam perhitungan $\mathrm{pH}$ larutan penyangga. Hal ini didukung dengan bukti nilai siswa pada larutan penyangga yang bersifat konseptual rata-rata $80 \%$ siswa menjawab benar, sedangkan yang bersifat perhitungan (dalam hal ini perhitungan $p \mathrm{H}$ larutan) rata-rata hanya $25 \%$ siswa yang menjawab benar. Perhitungan $\mathrm{pH}$ larutan penyebab utama siswa gagal mancapai KKM (kriteria ketuntasan minimum). Ada terdapat kesamaan dan kemiripan kasus dengan laporan terdahulu (Nurhujaimah dkk., 2016).

Pada dasarnya perhitungan $\mathrm{pH}$ larutan peyangga yang memiliki karakteristik rumus perhitungan yang berbeda dengan materi sebelumnya (asam basa dan hidrolisis). Pada materi asam basa, hidrolisis garam, dan larutan menyangga sama-sama memiliki kompetensi berupa perhitungan $\mathrm{pH}$. Hal inilah yang menjadi penyebab siswa mengalami miskonsepsi sehingga siswa banyak yang tidak dapat menjawab dengan benar. Selain itu ada juga siswa tidak mampu menjawab. Penyebab miskonsepsi yang terjadi di SMA Jenamas 1 ini hampir sama dengan miskonsepsi yang terjadi pada penelitian sebelumnya (Parastuti dan Ibnu, 2016). Dimana miskonsepsi disebabkan oleh lemahnya pengetahuan awal, permasalahan kegunaan dan rumus matematika, kurang memahami konteks materi, permasalahan generalisasi masalah dalam menjawab soal. Dalam hal ini berkemungkinan juga dapat disebabkan oleh kegiatan pembelajaran yang dilakasanakan 
sejauh ini dapat dikatakan masih pasif dan penggunaan media pembelajaran yang belum diterapkan secara maksimal. Pembelajaran sejauh ini masih terpusat pada guru yang dapat mengakibatkan siswa kurang aktif.

Dengan penelitian, pengumpulan data, dan informasi dengan baik, maka akan didapatkan kerangka untuk perencanaan membuat desain media kartu. Selanjutnya dilakukan pengembangan desain bentuk awal produk. Hal ini ditujukan agar materi menarik perhatian, dapat diterima siswa, dan digunakan agar dapat meningkatkan aktivitas siswa.

\section{Desain Produk}

Desain produk mengacu yang dibuat mengacu kepada kerangka yang dibuat. Produk yang dibuat disesuaikan dengan pertimbangan proses pembelajaran, keadaan sekolah, sarana dan prasarana yang ada disekolah, kurikulum serta karakteristik siswa di SMAN 1 Jenama. Selain itu hasil riset terdahulu yang berhubungan dengan miskonsepsi memandu peneliti untuk mendesain produk sehngga dapat menimalisir potensi miskonsepsi dan proses pembelajaran menjadi lebih menarik dan aktif.

Kartu soal yang didesain terdiri dari tiga jenis kartu yaitu, kartu soal, kartu petunjuk dan kartu jawaban. Ini didesain dengan sesuai dengan standar kompetensi dan indikator yang telah ditetapkan. Kartu ini akan disajikan dalam bentuk belajar interaktif bermain untuk menarik perhatian siswa dan dapat dipahami siswa dengan baik. Perhitungan $\mathrm{pH}$ larutan penyangga terdiri dari perhitungan $\mathrm{pH}$ larutan penyangga asam secara langsung dan tidak langsung dan perhitungan $\mathrm{pH}$ larutan penyangga basa secara langsung dan tidak langsung serta penambahan air dan senyawa yang bersifat asam atau basa. Desain menggunakan warna latar berupa warna merah dan biru ini ditujukan untuk kembali mengingatkan dan menguat konsep asam basa (sebelum larutan penyangga). Sebagaimana diketahui pada materi asam basa, bahwa asam mampu merubah warna kertas lakmus biru menjadi merah dan merah akan tetap merah. Warna merah ini merepresentasikan bahwa untuk kasus larutan penyangga yang bersifat asam. Sedangkan warna biru merepresentasikan larutan menyangga yang bersifat basa. Pada materi asam basa diketahui bahwa basa mampu merubah warna lakmus merah menjadi biru sedangkan biru akan tetap biru bila dikenai basa. Ini adalah satu cara untuk menguatkan kembali pemahaman siswa untuk meminimalisir sumber utama miskonsepsi dan menggiring /menguatkan daya analisa siswa(Parastuti dan Ibnu, 2016). Dalam hal ini siswa sudah bisa memprediksikan hasil perhitungan $\mathrm{pH}$ yang akan didapatkan sebab jika ia asam maka pasti di bawah 7 dan basa pasti di atas 7. Selain itu, siswa akan bisa menalar sendiri benar atau salah jawabannya. Jika salah atau tidak sesuai nalarnya mungkin siswa mengecek kembali rumus dan perhitungannya. Dalam hal ini potensi yang menyebabkan miskonsepsi sebagaimana dijelaskan dalam penelitian terdahulu (Marsita dkk., 2010)(Yunitasari dkk., 2013)(Parastuti dan Ibnu, 2016)(Maratusholihah dkk., 2017b) dapat diantisipasi.

Hasil desain akhir yang dihasilkan untuk kartu soal dapat ditunjukkan pada gambar 1 . Gambar 1 ini merepresentasian soal yang berhubungan dengan pembuatan larutan penyangga secara langsung. Gambar A dan B menunjukkan bagian depan untuk kartu soal dari gambar1 $\mathrm{C}$ dan D yang dianggab menarik bagi siswa dan keduanya harus sama. Gambar $1 \mathrm{C}$ dan $\mathrm{D}$ merupakan bagian belakang kartu soal yang bersifat asam dan basa secara berurutan. Gambar yang tersaji berupa gamber doraemon dan gambar siswa dan siswa membaca diangggab menarik perhatian. 

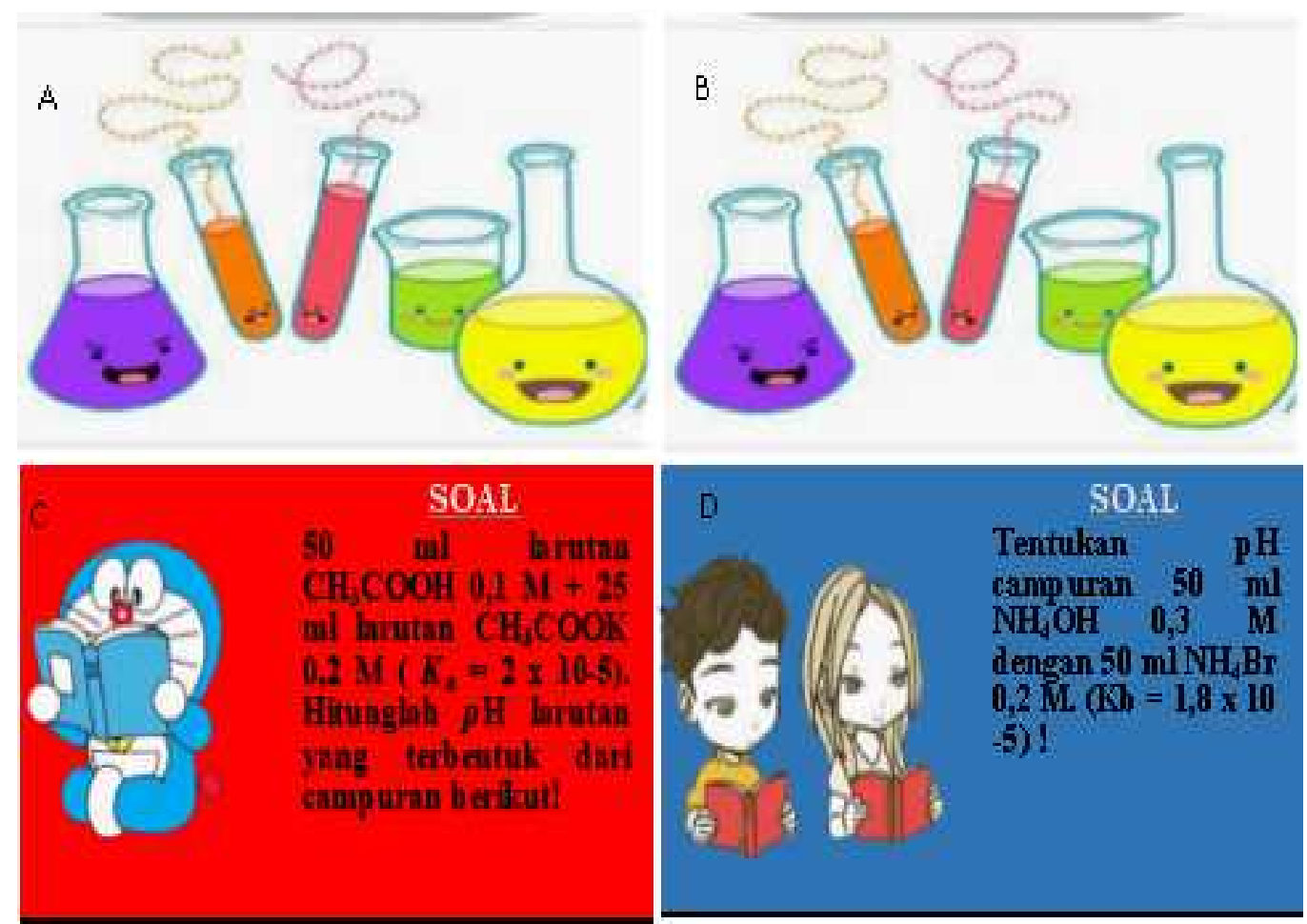

Gambar 1. Desain bagian depan dan belakang media kartu soal A) Bagian Depan Kartu

Soal Asam, B) Bagian Depan Kartu Soal Basa, C) Desain Bagian Belakang

Kartu Soal Asam, D) Desain Bagian Belakang Kartu soal Basa

Pada gambar 2 merupakan contoh kartu soal berupa petunjuk dan jawaban. Kartu ini memiliki jumlah kartu yang berbeda-beda, ini tergantung pada jenis soal yang akan diselesaikan, contohnya pada soal perhitungan $\mathrm{pH}$ larutan penyangga asam secara tidak langsung dimana kartu petunjuknya memiliki 7 buah kartu petunjuk penyelesaian soal sampai pada perhitungan akhir $\mathrm{pH}$ larutan. Adapun ketujuh langkah kartu petunjuk tersebut diantaranya : 1) Rumus dari menghitung konsep mol , 2) Senyawa-senyawa yang bersifat asam dan basa, 3) Cara melakukan persamaan reaksi, 4) Cara menghitung pereaksi pembatas, 5) Cara penguraian senyawa garam,
6) Rumus penyangga asam, 7) rumus perhitungan $\mathrm{pH}$ larutan.

Tujuan dari pembuatan kartu petunjuk ini, agar siswa dapat mengingat langkah demi langkah penyelesaian soal perhitungan $\mathrm{pH}$ larutan penyangga yang bersifat asam maupun basa. Sehingga dapat membantu siswa membedakan penggunaan rumus secara benar pada soal. Kemudian yang terakhir desain kartu jawaban dimana kartu ini memiliki jumlah yang sama dengan kartu petunjuk sesuai dengan soal yang digunakan yang berisi jawaban-jawaban dari tiap langkah penyelesaian soal sampai pada hasil akhir perhitunga $\mathrm{pH}$ larutan. 

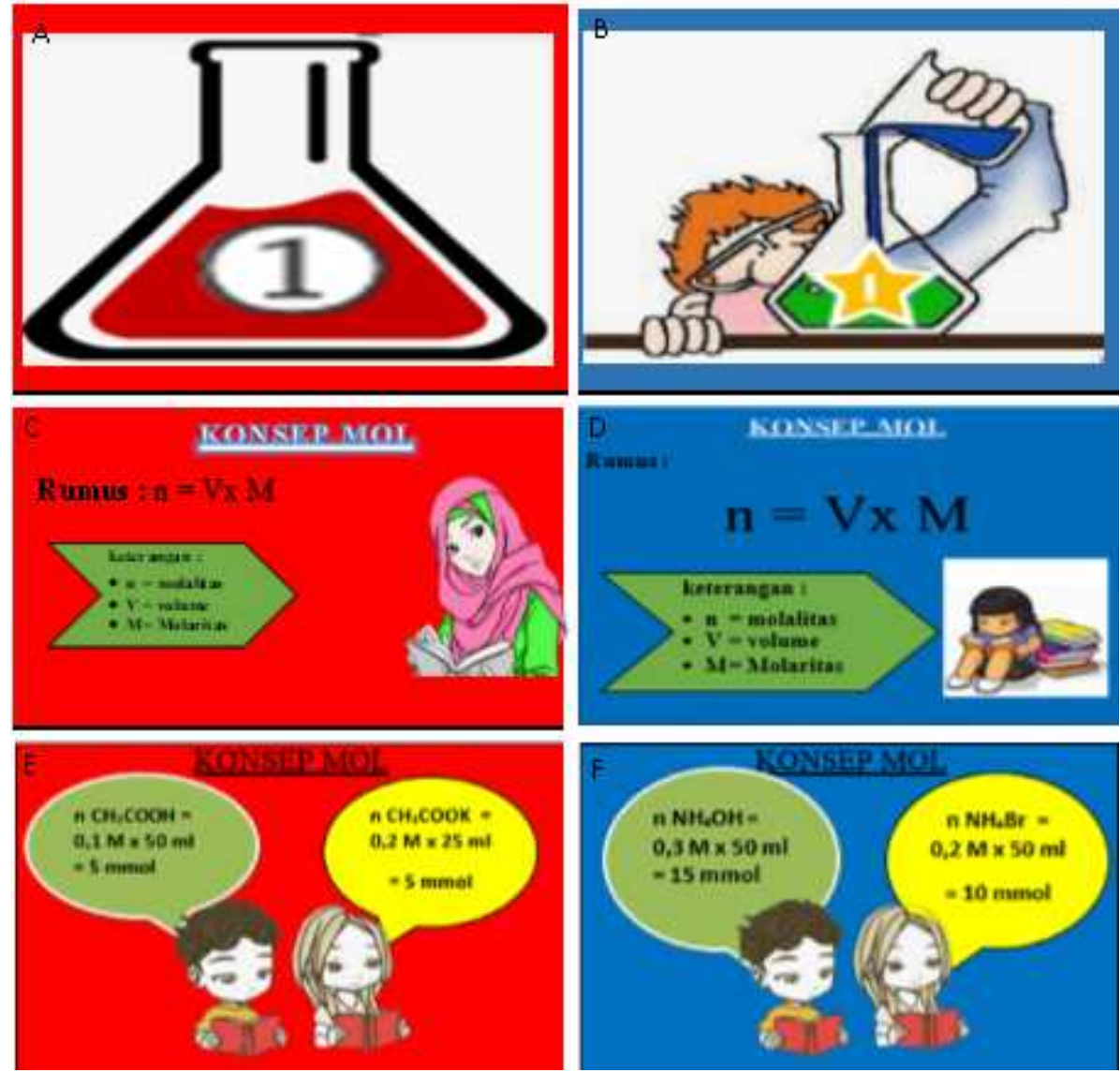

Gambar 2. Kartu soal berupa petunjuk dan jawaban A) Desan Bagian Depan Kartu Petunjuk dan Kartu jawaban Asam, B) Desan Bagian Depan Kartu Petunjuk dan Kartu jawaban Basa, C) Desain Bagian Belakang Kartu Petunjuk Asam, D) Desain Bagian Belakang Kartu Petunjuk Basa, E) Desan Bagian Belakang Kartu jawaban Asam, F) Desan Bagian Depan Kartu jawaban Basa. 
Adanya siswa yang menggunakan hijab dan tidak menunjukkan keberagaman siswa di SMAN 1 Jenamas dan ini dianggab menarik. Sementara itu gambar anak duduk membaca menggambarkan usaha.

Agar materi menarik perhatian dan dapat diterima siswa. Penggunaan kartu disajikan dalam bentuk permainan. Kartu yang telah didesain, digunakan agar dapat meningkatkan aktivitas siswa. Peraturan penggunaan kartu tersebut adalah sebagai berikut: (1) Guru membagi siswa menjadi beberapa kelompok dimana masing-masing kelompok terdiri dari 2 orang, (2) Guru akan membagikan kartu petunjuk kepada masing masing kelompok, (3) Guru akan membagikan kartu soal pada salah satu siswa yang berpasangan, (4) Guru meminta siswa yang menerima kartu soal menyelesaikan soal yang terdapat dalam kartu, (5) Pasangan siswa yang mengambil kartu soal, akan memiliki kunci jawaban soal yang dikerjakan oleh temannya, (6) Guru meminta siswa yang memegang kunci jawaban untuk mengawasi temannya dalam menyelesaikan soal, (7) Jika siswa yang mengerjakan soal salah dalam memasukan rumus, maka dia bisa mengambil kartu petunjuk, dan (8) Pemenang permaianan dilihat dari siswa yang menjawab soal dengan benar tanpa megambil kartu petunjuk atau yang paling sedikit mengambil kartu petunjuk yang akan mendapatkan poin tertinggi.

\section{Validasi Desain, Uji coba Produk dan Revisi Produk}

Berdasarkan hasil angket oleh validator desain media kartu soal ini sudah 3 kali mengalami perbaikan sampai media kartu soal ini layak digunakan sebagai media pembelajaran. Rata - rata jumlah skor yang didapat dari ketiga validator adalah sebesar
98,6\% dengan kriteria sangat layak. pada uji coba skala kecil data yang diperoleh untuk mengetahui kalayakan media kartu soal yang dikembangkan, dengan uji coba peserta didik kelas XII IPA SMAN 1 Jenamas yang berjumlah 10 orang. Berdasarkan data dari hasil angket yang didapatkan menyatakan ada 8 peserta didik menyatakan kriteria sangat baik dengan nilai rata - rata sebesar 17,6 dan ada 2 peserta didik yang menyatakan kriteria baik dengan nilai rata - rata sebesar 14. Maka didapat perolehan rata - rata dari nilai seluruh peserta didik adalah 16,9 yang masuk pada kriteria sangat baik. Pada uji skala besar yang dilakukan seluruh pada peserta didik kelas XI IPA SMAN 1 Jenamas yang dilakukan oleh 16 orang untuk mengetahui kelayakan media kartu soal yang dikembangkan. Pada tahap ini kegiatan pembelajaran dilakukan sesuai dengan RPP yang dilakukan 4 kali pertemuan dengan alokasi waktu setiap kali pertemuan 2 x 45 menit. Berdasarkan ratarata perolehan angket respon peserta didik memperoleh nilai sebesar 19,6 dengan keriteria sangat baik.

\section{SIMPULAN}

Dari hasil uji coba kelayakan media kartu soal dapat dikatakan media kartu soal yang dibuat layak digunakan sebagai media pembelajaran untuk mempermudah peserta didik dalam perhitungan $\mathrm{pH}$ larutan penyangga.

\section{DAFTAR RUJUKAN}

Assriyanto, K. E., Sukardjo, J. S., dan Saputro, S. (2014): Pengaruh Model Pembelajaran Berbasis Masalah Ditinjau dari Kreativitas Siswa pada Materi Larutan Penyangga di SMAN 2 Sukoharjo Tahun Ajaran 2013/2014, 
Jurnal Pendidikan Kimia (JPK), 3(3), 89-97.

Badlisyah, T., dan Maghfirah, M. (2017): Penggunaan Macromedia Flash Pada Materi Larutan Penyangga Terhadap Hasil Belajar Siswa Kelas XI MAN Darussalam, Lantanida Journal, 5(1), 42-58.

Dony, N., Nuriah, Jurniah, dan Karina (2018): Media Pembelajaran Kimia Menggunakan Kartu, BRILIANT: Jurnal Riset dan Konseptua, 3(4), 405-413.

Maratusholihah, N. F., Rahayu, S., dan Fajaroh, F. (2017): Analisis Miskonsepsi Siswa SMA pada Materi Hidrolisis Garam dan Larutan Penyangga, Jurnal Pendidikan: Teori, Penelitian, dan Pengembangan, 4(July), 137-143.

Maratusholihah, N. F., Rahayu, S., dan Fajaroh, F. (2017): Hidrolisis Garam dan Larutan Penyangga, Jurnal Pendidikan: Teori, Penelitian, dan Pengembangan, 2(7), 919-926.

Marsita, R. A., Priatmoko, S., dan Kusuma, E. (2010): Analisis Kesulitan Belajar Kimia Siswa SMA dalam Memahami Materi Larutan Penyangga dengan Menggunakan Two-Tier Multiple Choice Diagnostic Instrument, Jurnal inovasi Pendidikan Kimia, 4(1), 512520.

Marsiti, C. I. R. (2011): Upaya Peningkatan Mutu Pendidikan Sekolah Menengah Kejuruan Melalui Pengembangan Profesionalisme Guru, Jurnal Pendidikan Vokasi, 1(1), 157-168.
Nana, S. (2004): Dasar-dasar proses belajar mengajar (Sinar Baru Algensindo, Ed.), Bandung.

Novauli, F. (2015): Kompetensi Guru dalam Peningkatan Prestasi Belajar pada Smp Negeri dalam Kota Banda Aceh, Pascasarjana Universitas Syiah Kuala, 23(1), 45-67.

Nurhujaimah, R., Kartika, I. R., dan Nurjaydi, M. (2016): Analaisa Miskonsepsi Siswa Kelas XI pada Materi Larutan Penyangga Menggunakan Instrumen Tes Three Tier Multiple Choice, Jurnal Penelitian Pendidikan, 19(1), 15-28.

Parastuti, W. I., dan Ibnu, S. (2016): Miskonsepsi Siswa pada Materi Larutan Buffer, Jurnal pendidikan: Teori, Penelitian, dan Pengembangan, (2007), 2307-2313.

Pratiwi, D. M. (2015): Pengembangan LKS Praktikum Berbasis Inkuiri pada Pokok Bahasan Larutan Penyanngga Kelas XI IPA SMA, Jurnal Pendidikan Kimia, 4(2), 32-37.

Rahmadhani, A., Kartika, I. R., Kimia, J., dan Jakarta, U. N. (2013): Peningkatan Efektivitas Pembelajaran Larutan Penyangga Melalui Pendekatan SAVI (Somatis, Auditori, Visual, dan Intelektual) Pada Siswa Kelas XI SMAN 21 Jakarta, JRPK: Jurnal Riset Pendidikan Kimia, 3(1), 156-165.

Yakina, Kurniati, T., Fadhilah, R. (2017): Analisis Kesulitan Belajar Siswa Pada Mata Pelajaran Kimia Kelas X di SMA Negeri 1 Sungai Ambawang, Ar-Razi Jurnal Ilmiah, 5(2), 287-297. 
Yunitasari, W., Susilowati, E., dan Nurhayati, D. (2013): Pembelajaran Direct Instruction Disertai Hierarki Konsep Untuk Mereduksi Miskonsepsi Siswa Pada Materi Larutan Penyangga Kelas XI Semester Genap SMA Negeri 2 Sragen Tahun Ajaran 2012 / 2013, Jurnal Pendidikan Kimia (JPK), 2(3), 182190. 